\title{
Coagulation Process for Removing Algae and Algal Organic Matter-An Overview
}

\author{
Djamel Ghernaout ${ }^{1,2}$, Noureddine Elboughdiri1,3, Saad Ghareba1,4, Alsamani Salih ${ }^{1,5}$ \\ ${ }^{1}$ Chemical Engineering Department, College of Engineering, University of Ha'il, Ha'il, KSA \\ ${ }^{2}$ Chemical Engineering Department, Faculty of Engineering, University of Blida, Blida, Algeria \\ ${ }^{3}$ Département de Génie Chimique de Procédés, Laboratoire Modélisation, Analyse, et Commande des systèmes, Ecole Nationale \\ d’Ingénieurs de Gabès (ENIG), Gabès, Tunisia \\ ${ }^{4}$ Department of Chemical and Petroleum Engineering, El Mergib University, Al Khums, Libya \\ ${ }^{5}$ Department of Chemical Engineering, Faculty of Engineering, Al Neelain University, Khartoum, Sudan \\ Email: ^djamel_andalus@hotmail.com
}

How to cite this paper: Ghernaout, D., Elboughdiri, N., Ghareba, S. and Salih, A. (2020) Coagulation Process for Removing Algae and Algal Organic Matter-An Overview. Open Access Library Journal, 7: e6272.

https://doi.org/10.4236/oalib.1106272

Received: March 25, 2020

Accepted: April 6, 2020

Published: April 9, 2020

Copyright (C 2020 by author(s) and Open Access Library Inc.

This work is licensed under the Creative Commons Attribution International License (CC BY 4.0).

http://creativecommons.org/licenses/by/4.0/

\begin{abstract}
In drinking water sources, seasonal algal blooms have augmented greatly during the last decades following the elevated temperature and nutrient loading in surface water because of agricultural and surface runoff. More than 95\% of algal cells may be retained via coagulation/flocculation techniques. Nevertheless, algal organic matter (AOM) stays not eliminated well throughout coagulation, therefore it provokes many working dares in potable water treatment. This work aims to discuss the performance of coagulation on AOM reduction. The main pathway of algae and AOM reduction stays charge neutralization $(\mathrm{CN})$ at an optimum $\mathrm{pH}$ of about 6.0. More research has to follow the reduction of low-molecular weight AOM, reluctant to coagulate, with additional treatment methods to diminish its negative influence on water safety. As dissolved microcystins (MCs) are efficaciously eliminated via $\mathrm{CN}$, enhanced coagulation (EC) would be more suitable for their elimination. On the other hand, some precautions must be followed to guarantee that the acid injection has not a secondary impact in the form of algaecide treatment to avert the dissolved MCs concentration augmentation. Consequently, both algae and dissolved MCs may be efficiently removed by EC when appropriate rapid mixing and acid/coagulant dosage are guaranteed.
\end{abstract}

\section{Subject Areas}

Biological Chemistry

\section{Keywords}

Algae, Algal Organic Matter (AOM), Coagulation/Flocculation, Microcystins 
(MCs), Enhanced Coagulation (EC), Disinfection By-Products (DBPs)

\section{Introduction}

Nowadays, around 1.1 billion people worldwide need an approach to ameliorated water supply, and approximately 2.4 billion people are down the hazard of subjections to waterborne diseases (like typhoid fever, cholera, diarrhea, etc.) due to the unsuitable sanitation plants [1]. More than 1.8 billion people will undergo absolute water lack, and $2 / 3$ of the world will be living below water-stressed circumstances by 2025 [2]. The grave condition requests efficient handling of water resources, source water safeguards, and expansion of cost-efficient treatment techniques [1].

During the last years, surface waters (like lakes, reservoirs, rivers, etc.) remain as crucial potable water sources worldwide that have encountered changing levels of eutrophication [1] [3] [4] [5]. Because of eutrophication, global eruptions of algal blooms have provoked serious decay of water quality in several regions [6]. In a general manner, algal blooms take place in the occurrence of elevated levels of nutrients, particularly with warm, sunny, and calm hydraulic circumstances. Harmful algal blooms (HABs) are propagations of microscopic algae that considerably induce health dangers to nature via generating toxins (i.e., microcystins (MCs)) or bioactive compounds that gather in shellfish or fish, or via the aggregation of the biomass of Microcystis aeruginosa that then impacts the co-existing organisms and changes food chains in unfavorable fashions [7]. The beginning of algal bloom conducts to the doom of the aquatic organisms and cattle as well as dangerous water quality decay [1].

The occurrence of algae in water touches numerous water treatment techniques like coagulation, sedimentation, and filtration in potable water treatment plants (WTPs) [1]. Further, toxins formed by many cyanobacteria and degraded algal matter provoke odor issues [8], conducting to grave decay of water quality. Moreover, the eruption of algal bloom or doom of algae liberates algal organic matters (AOMs) in water, which are hidden precursors of the disinfection by-products (DBPs) produced because of chlor(am)ination. Sometimes, chemical pre-oxidation and enhanced coagulation (EC) are implemented to eliminate algae. Elevated injection of pre-oxidants could conduct to the cell harm provoking the liberation of intracellular substances comprising odors and toxins. Algal matter in water induces numerous troubles like 1) the elevation of coagulant dose, 2) filter blocking and lessening of the filter running cycle, and elevating the hardness of backwash, 3) augmentation of the chlorine request and generation of DBPs, 4) formation of odorous substances, toxicity, and decay of water taste, 5) elevation of the hazard of waterborne organism reproduction in the distribution system [1] [9].

Lately, algal blooms have induced many grave water supply crises in China [1]. Ten years ago, a water quality survey of 26 major lakes and reservoirs of 
China depicted that the percentage of the examined water source with class I III, IV - V and worse than class $\mathrm{V}$ (water quality decreases with increasing class) were $42.3 \%, 50 \%$, and $7.7 \%$, respectively [10]. There are numerous species of algae existing in surface water. Following the survey of water quality of 11 reservoirs in Fujian Province, it was found that the controlling algal species were Chlorophyta (40.58\%), Cyanophyta (22.91\%), Bacillariophyta (21.61\%), and Chrysophyta (6.91\%) [11]. Lake Taihu, the third-largest freshwater lake in China, a large shallow eutrophic lake, is controlled by Microcystis spp. In 2007, a serious cyanobacterial bloom occurred in Lake Taihu, leaving about two million inhabitants without potable water for over a week [12]. During the last decade, $\mathrm{Wu}$ et al. [13] examined 51 main rivers in China to estimate the influence of nutrients on algae biomass throughout summer and winter in inflows of Taihu Ba$\sin [1]$.

In North America and internationally, there has been expanding worries on the subject of the cyanobacterial expansion for the massive effect that immoderate bloom and the carcinogenic algal toxins give rise [1]. Huge algal blooms have been seen via satellite in the lower Great Lakes area since the mid-1990s [12]. In 2011, the western basin of Lake Erie had undergone the largest bloom since 2002 [14]. Expanding over $5000 \mathrm{~km}^{2}$, the bloom contained mostly toxic Microcystis and conducted to the closure of beaches and potable water advisories in both Canada and the US [15]. The 2013 bloom was categorized as one of the worst on record since it was the first time a WTP in Ohio was taken off-line due to the level of cyanotoxins surpassing the treatment capability [16]. In 2014, there was a shutdown of drinking water supplies in the city of Toledo because of cyanobacterial bloom, conducted to more than 400,000 inhabitants with no access to water for many days. Therefore, five years ago, a novel Drinking Water Protection act had been suggested which requests the USEPA to develop and submit a plan for estimating and controlling hazards concerning algal toxins in potable water provided by public water facilities [1] [17].

The City of Beijing and numerous smaller cities across northern China are subjected to constant water shortage and decadent source water quality [1]. With a view to dealing with the pressing water lack, the Chinese Central Government proposed the "South to North Water Diversion (SNWD)" project. The middle route of the SNWD project originates at the Danjiangkou reservoir and tries to transfer 30 million $\mathrm{m}^{3}$ of water to northern China every day. A fraction of the transferred water will be stored in the Miyun reservoir and employed as a novel water source for the City of Beijing. The total length of the main canal, which crosses the North China Plain, is around $1277 \mathrm{~km}$, with an annual diversion capacity of $9.5 \times 10^{9} \mathrm{~m}^{3}$ water; about $1.0 \times 10^{9} \mathrm{~m}^{3}$ of diversion alone is allocated to Beijing as the source water for WTPs [18]. With the SNWD project completed by 2014, two new WTPs have been built by Beijing Waterworks Group with an additional water capacity of 1000 million liters per day. In addition, the existing WTPs must be upgraded in order to accommodate the change of water sources [1]. 
Taking into account the numerous properties of novel water sources and the shortage of technical expertise in building and running such huge water infrastructure, worries have surged in terms of the uncertainty of water quality, as well as the influence of the environmental circumstances in the storage reservoirs and performance of existing water treatment operations [1]. The techniques for controlling and predicting were largely investigated to make sure water diversion capability [19]. Because of runoff and rainwater infiltration, water quality is adversely influenced in several portions of the channel. In the water body of the SNWD project, 31 sorts of phytoplanktons were observed in the winter; 15 found species were diatom (48.39\%), seven were blue algae, six were green algae, and one each of Cryptophyta, Dinoflagellate, and Chrysophyceae was present. Founded on overall monitoring data gathered in China, different chemical and microbiological pollutants have been defined in several lakes and reservoirs. Between the most significant are pathogenic protozoans (Giardia and Cryptosporidium), algal toxins, organic micropollutants and DBPs following from chlorination. Multi-barrier treatment strategies involving physicochemical pre-treatment, activated carbon adsorption, membrane filtration, and disinfection (like UV + chlorine) are needed to guarantee a secure supply of potable water [20] [21] [22]. Such techniques are accepted for reducing natural organic matter (NOM) extracted from detritus plant and animal materials, restricted comprehension, and technical expertise remain for algal matter treatment, needing control laboratory investigations to promote the best treatment choices. Yielded findings could be employed for methodical combination and process regulation leading to major savings in capital, operation, and maintenance prices thanks to the scale of water treatment infrastructure [1].

\section{Algae and Algal Organic Matter (AOM)}

Present in many natural environments comprising freshwater, marine water, moist rocks, and wet soils, algae are a set of eukaryotic oxygenic photosynthetic microorganisms with organelles like chloroplast and nucleus. For their nourishment and development, they need sunlight, carbon dioxide, water, and nutrients such as nitrogen and phosphorus [1]. Following cell wall chemistry, morphology, chlorophyll and accessory pigments, algae are categorized. Green algae, dinoflagellates, diatoms, euglenoids, brown algae, golden-brown algae, and red algae are the frequently detected algal groups in aqueous systems [2]. Viewed like the major producers, algae possess the most important favorable contribution in the aquatic food web; however, their occurrence in drinking water sources provokes several dares [23]. In this work, the problems linked to the existence of dissolved organic matter (DOM) resulted from algae are discussed in this section.

\subsection{Algal Species in the Potable Water Source}

Through the world, the water quality of lakes and reservoirs changes greatly; 
nevertheless, algal species occurring in an aquatic medium alter in a short domain [23]. As an illustration, diatoms grow in cold water, whilst green and blue-green algae are prevalent in warm, shallow and nutrition-rich water bodies [1].

Usually noticed, algae and cyanobacteria in potable water sources (Table 1) comprise blue-green algae (Cyanophyceae), green algae (Chlorophyceae), euglenoids (Euglenophyceae), dinoflagellates (Dinophyceae), cryptomonads (Cryptophyceae), yellow-green algae (Xanthophyceae), golden algae (Chrysophyceae) and diatoms (Bacillariophy) [1].

\subsection{Algal Organic Matter (AOM) Level vs. Cultivation Time}

Because of metabolic excretion and autolysis of algal cells, AOM is liberated into water [1] [5]. AOM is classified as extracellular organic matter (EOM) [24], which is expelled to the encompassing medium via living algae cells [25], and intracellular organic matter (IOM), which is secreted because of natural rupture of cells in the declining growth phase. IOM could be deliberately liberated throughout pre-oxidation [26] [27] (in treatment plants), grinding [27] [28] [29] or a freezing-thawing sequence [1] [24].

Table 1. List of frequent algae found in potable water sources [1].

\begin{tabular}{|c|c|c|c|}
\hline Algae species & Features & Development circumstances & Usual genera \\
\hline $\begin{array}{l}\text { Blue-green algae } \\
\text { (Cyanobacteria) }\end{array}$ & $\begin{array}{l}\text { Carry phycocyanin, allophycocyanin, and chlorophyll a; } \\
\text { give blue, blue-green color. Generate cyanotoxins, carry } \\
\text { out oxygenic photosynthesis. }\end{array}$ & $\begin{array}{l}\text { Warm, eutrophic water, } \\
\text { above } 25^{\circ} \mathrm{C}\end{array}$ & $\begin{array}{c}\text { Anabaena, Aphanizomenon, } \\
\text { Microcystis, Oscillatoria }\end{array}$ \\
\hline Green algae & $\begin{array}{l}\text { Carry chlorophyll } a \text { and } b \text {, green color. Some genera are } \\
\text { related to disagreeable taste and odor and filter clogging } \\
\text { issues. }\end{array}$ & Summer & $\begin{array}{l}\text { Ankistrodesmus, } \\
\text { Chlamydomonas, Chlorella, } \\
\text { Scenedesmus }\end{array}$ \\
\hline Euglenoids & $\begin{array}{l}\text { Carry chlorophyll } a \text { and } b \text {, green color, capable of } \\
\text { photosynthesis. }\end{array}$ & Summer & \\
\hline Dinoflagellates & $\begin{array}{l}\text { Capable of photosynthesis and feeding on bacteria, } \\
\text { small planktonic algae. Brownish color, some genera are } \\
\text { linked with an undesirable taste and odor issues, } 90 \% \text { of } \\
\text { them live in the ocean. }\end{array}$ & Summer and fall & Ceratium, Peridinium \\
\hline Cryptomonads & $\begin{array}{l}\text { Carry chlorophyll } a \text { and } c 2 \text {, and pigments masking the } \\
\text { color of chlorophyll. May seem blue, blue-green, } \\
\text { reddish, yellow-brown, olive-green. Light sensitive and } \\
\text { prefer nutrient-enriched water. }\end{array}$ & $\begin{array}{l}\text { Temperate climate throughout } \\
\text { winter }\end{array}$ & $\begin{array}{c}\text { Cryptomonas, Chroomonas, } \\
\text { Rhodomonas }\end{array}$ \\
\hline Yellow green algae & $\begin{array}{l}\text { Rarely existing in large quantities. Carry chlorophyll a, } \\
\beta \text {-carotene, and many pigments. Look yellow-green, } \\
\text { bright green. }\end{array}$ & Low temperature & Tribonema \\
\hline Golden algae & Frequently related to unwanted taste and odor. & Summer & Synura, Dinobryon \\
\hline Diatom & $\begin{array}{l}\text { Frequently related to undesirable taste, odor and filter } \\
\text { clogging. Seem in brown color. Siliceous cell wall } \\
\text { contains polymerized silicic acid. Perform oxygenic } \\
\text { photosynthesis at a water temperature of } 5^{\circ} \mathrm{C} \text {. }\end{array}$ & $\begin{array}{l}\text { Spring, oligotrophic waters, } \\
\text { optimum temperature } \\
\text { at } 10^{\circ} \mathrm{C}-20^{\circ} \mathrm{C}\end{array}$ & $\begin{array}{l}\text { Asterionella, Cyclotella, } \\
\text { Tabellaria, Fragilaria, Melosira }\end{array}$ \\
\hline
\end{tabular}


As a rule, the development of algae and bacteria remains a multiplex phenomenon with many catabolic and anabolic reactions conducting to cell division [30] [31]. Thus, both EOM and IOM change considerably with the algal species and could extend from a few $\mathrm{mg} / \mathrm{L}$ to about $100 \mathrm{mg} / \mathrm{L}$ [1]. AOM formation augments with cultivation time for all the algae studied [1].

Typically, a microbial growth curve is split into four major phases that is lag, exponential, stationary and decline phase [32]. For the reason that most algal cells display healthy unity in the initial stage when the cells are young and the medium is fresh, AOM in the medium is mostly attributed to EOM, with only a few IOM liberated at that period [33]. The EOM liberation rate is much bigger in the exponential phase than that in the stationary phase [34]. However, DOM contents generated from AOM extraction stay much greater in the stationary stage than that in the exponential stage [35]. The phenomenon of cell autolysis and rupture below poor nutrient circumstances conduct to IOM liberation into culture media with a noteworthy augmentation in AOM throughout the decline phase [1]. The IOM amount appears to be much greater than that of EOM in several situations (such as the dissolved organic carbon (DOC) of IOM from $M$. aeruginosa in the exponential phase is three to six times [1] bigger than the DOC from EOM. Consequently, it is essential to avert the algal cell breaking and the next liberation of AOM [23], which touches the performance of water treatment technologies [1]. With augmenting eutrophication of aquatic ecosystems, organic matter (OM) arising from algal cells constitutes a considerable part (up to $50 \%)$ of the NOM in surface waters [1] [26] [27].

\subsection{Characterization of Algal Organic Matter (AOM)}

The AOM carries many compounds like polysaccharides, oligosaccharides, proteins, peptides, amino acids, and traceable organic acid; further, the precise composition changes following algae species [1]. Researchers [1] prepared a comprehensive overview of the main constituents of diverse algae species [1]. The composition of some usually observed species is presented in Table 2 [1].

If juxtaposing to NOM [36], AOM seems to carry more organic nitrogen and hydrophilic content [37], less aromatic carbon content and much smaller specific ultraviolet absorbance (SUVA $<2 \mathrm{~L} / \mathrm{mg} / \mathrm{m}$ ) [26] [38] [39] [40] [41] [42]. It is mentioned that both EOM and IOM are hydrophilic with small SUVA [43]. Matched to EOM, IOM is richer in proteins or peptides, more hydrophilic with lower SUVA level. Molecular weight (MW) fractionation depicted that both EOM and IOM of cyanobacteria, green algae, and diatom carry big fractions of low-MW (below $1 \mathrm{k} \mathrm{Da}$ ) compounds and some high-MW (over $100 \mathrm{k} \mathrm{Da}$ ) polysaccharides [1]. IOM possesses a bigger part of total organic nitrogen. It as well carries a bigger portion of amino acids; however, it contains a smaller portion of aliphatic amines than EOM [1] [24].

To more categorize the composition of AOM, numerous techniques have been mentioned in the publications, comprising UV-visible absorbance, fluorescence/HPLC, excitation-emission matrix (EEM), Fourier transform infrared 
Table 2. Composition of different algal matter (\% of dry matter) [1].

\begin{tabular}{|c|c|c|c|}
\hline Alga & Carbohydrates & Protein & Lipids \\
\hline Anabaena cylindrical & $25-30$ & $43-56$ & $4-7$ \\
\hline Aphanizomenon flos-aquae & 23 & 62 & 3 \\
\hline Arthrospira maxima & $13-16$ & $60-71$ & $6-7$ \\
\hline Aulacoseira granulata f. curvata & 36.3 & 47.9 & 15.8 \\
\hline Chlamydomonas rheinhardii & 17 & 48 & 21 \\
\hline Chlorella pyrenoidosa & $24-28$ & $54-60$ & $11-12$ \\
\hline Chlorella vulgaris & $12-17$ & $51-58$ & $4-24$ \\
\hline Euglena gracilis & $14-18$ & $39-61$ & $14-20$ \\
\hline Merismopedia sp. & $35-57$ & $29-45$ & $\mathrm{NA}^{*}$ \\
\hline Microcystis aeruginosa & $4.0-10.1$ & $37-52$ & $\mathrm{NA}^{*}$ \\
\hline Oscillatoria sp. & $42-52$ & $41-48$ & $5-8$ \\
\hline Phaedactylum Tricornutum & $11.2-26.1$ & $36.4-53.2$ & $8.0-32.6$ \\
\hline Porphyridium cruentum & $40-57$ & $28-39$ & $9-14$ \\
\hline Scenedesmus obliquus & $10-27$ & $50-65$ & $7-14$ \\
\hline Scenedesmus quadricauda & $3.7-24.8$ & $4.4-9.5$ & $6.9-10.6$ \\
\hline Spirogyra sp. & $33-64$ & $6-20$ & $11-21$ \\
\hline Spirulina platensis & $8-14$ & $46-63$ & $4-9$ \\
\hline Syenchocaccus sp. & 15 & 63 & 11 \\
\hline
\end{tabular}

*NA: Not available.

spectrophotometry (FTIR), H-NMR spectroscopy [1]. Presently, the most frequently utilized techniques for the physicochemical categorization of AOM are: 1) DOC and dissolved organic nitrogen analysis, 2) spectrophotometry like ultraviolet (UV) absorbance and fluorescence-excitation emission matrix, 3) hydrophobicity analysis via resin fractionation, 4) MW distribution via high-performance size exclusion chromatography [1].

\section{Removing Algae and Algal Organic Matter (AOM) via Coagulation}

In surface water, colloids and suspended particles [44], comprising organic content (humic [45] [46] [47] [48] and fulvic acids) and inorganic minerals [49], bacteria [50] [51] [52] [53] [54], viruses [55] [56] [57] [58], and algae, play a part in turbidity, color [59] [60] [61], odors and tastes in the surface waters [62] [63] [64] [65] [66]. As illustrated in Figure 1, the size of particulates that could be eliminated via coagulation spreads from $0.001 \mu \mathrm{m}$ to $10 \mu \mathrm{m}$ [67] [68] [69] [70] [71]. Humic acid, viruses, bacteria and some species of algae and a part of their metabolites possess a particle size inside such span, and could be reduced with colloids [1] [72] [73] [74].

Present-day water treatment techniques furnish multiple barriers to assure 


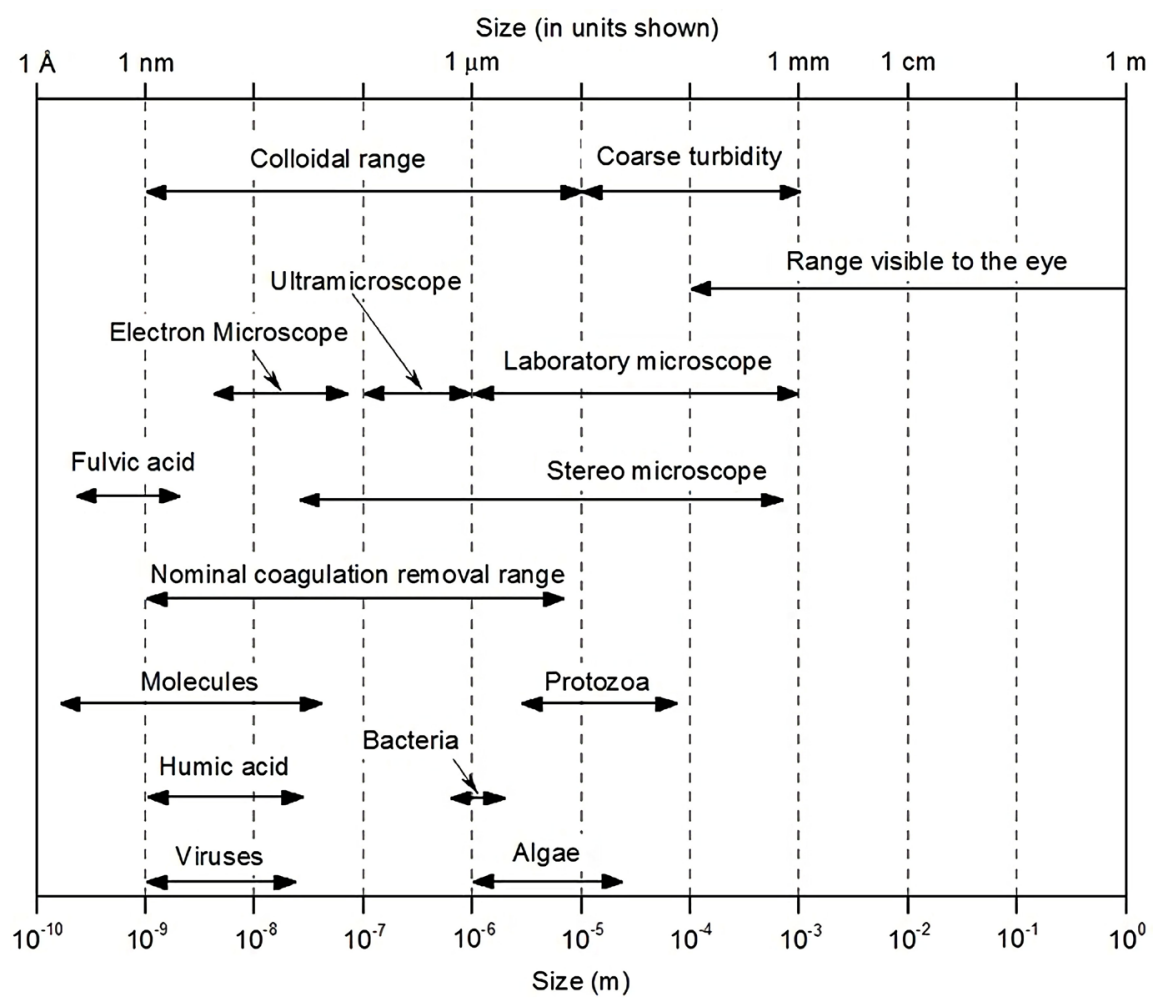

Figure 1. Particle size distribution in aqueous system [1].

drinking water, comprising pre-oxidation [75] [76], coagulation/flocculation [77]-[89], sedimentation and disinfection [90] [91] [92] [93] [94] (Figure 2) [1].

Raw water is pushed over a coarse filter, which eliminates large floating objects or suspended solids, like plastic bags, leaves, etc., without retaining dissolved organics, algae/cyanobacteria and their metabolites [37]. A not required pre-oxidation via chlorine [95], ozone or permanganate, and ferrate points to elevate the performance of downstream treatment, like coagulation; nevertheless, pre-oxidation methods destroy the membrane of algae and cyanobacteria provoking cell lysis and the liberation of algal toxins or IOM [9] [36]. The impact of pre-oxidation via permanganate and ozone on coagulation via aluminum sulfate (alum) to reduce $M$. aeruginosa in aqueous solution was formerly studied by scientists [1] who established that that pre-oxidation ameliorated cell elimination throughout coagulation; nevertheless, more nitrogenous and lower-MW substances were formed due to the ravaged cell walls and membrane following pre-oxidation [96]-[101]. The organic matter adsorbed on the cells' surface could be liberated following pre-oxidation with permanganate even without provoking cell lysis [1]. Different research mentioned that permanganate pre-oxidation conducted to the liberation of EOM from cells of Chlorella sp. [1] [9].

\subsection{Coagulation/Flocculation}

As illustrated in Figure 2, the coagulation process remains the basic and most 


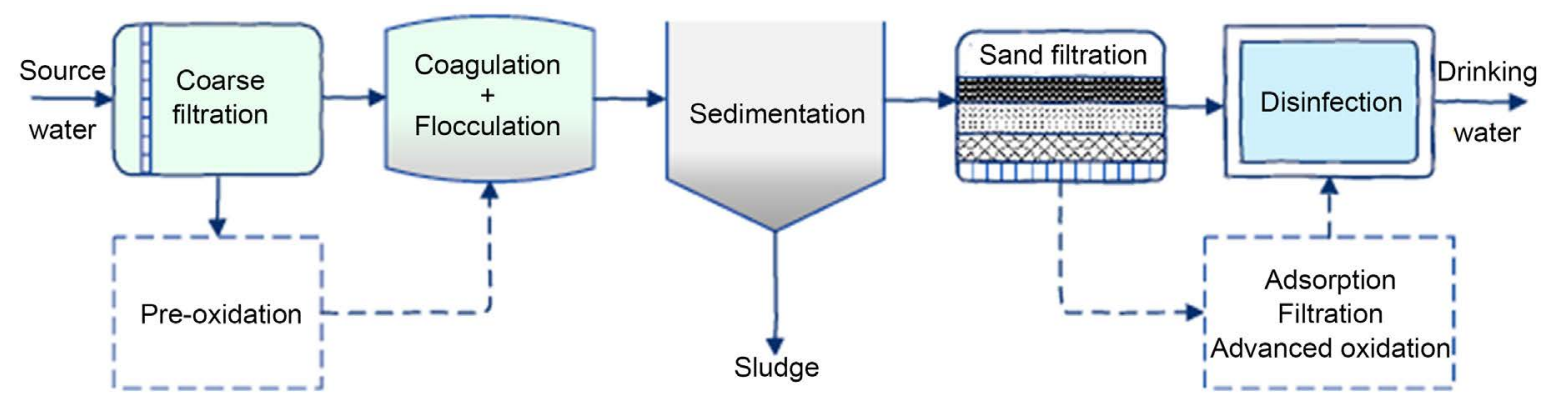

Figure 2. Overview of potable water treatment [1].

frequently employed technique for both particulates and organic matter elimination in treatment plants [1] [36] [102] [103] [104] [105]. Attributed to the coagulation process, complete or partial reduction of suspended particles and colloids, dissolved organic and/or inorganic matter, microorganisms such as bacteria, algae or viruses, could take place [106]. In the water treatment industry, coagulants that are utilized comprise inorganic salts (mainly iron and aluminum), inorganic polymers (like polymeric aluminum chloride (PACl)) and organic polymers with elevated MW and long chains [107]. As coagulants, injecting iron or aluminum salts aims to neutralize the negatively charged colloids and suspended particles to avoid electrostatic repulsion among them and supporting micro-flocs production [108]. Then, the generated micro-flocs mass and produce bigger particles, which are reduced via deposition [109]. In the flocculation method, numerous kinds of polyelectrolyte may as well be introduced as coagulant aids or flocculants, which could be helpful in eliminating turbidity in conjunction with metal coagulants; however, they could possess less importance in dealing with DBPs precursors due to their ineffectiveness in the elimination of DOM [1] [9] [36].

\subsubsection{Circumstances Impacting Coagulation/Flocculation}

There are diverse variables that touch the coagulation efficiency, comprising coagulant type, injection, water characteristics, and coagulation circumstances (Table 3) [1] [9] [36].

The two largely utilized coagulants remain metal salts and polymers, and the most frequent metallic coagulants in potable water treatment stay alum and ferric chloride [1] [36]. Adopting a particular coagulant is a function of diverse parameters involving the requested elimination, cost, availability, storage, application and safety. The most crucial variable touching the performance of metal-based coagulants stays $\mathrm{pH}$ [1] [36]. At the most favorable $\mathrm{pH}$, the solubility of hydrolyzed alum products is negligible and the main part of coagulant is transformed into flocs [36]. Negatively charged aluminum species are formed if $\mathrm{pH}$ is augmented above the optimal level, and the positively-charged dissolved aluminum species are generated at a lower $\mathrm{pH}$ [36]. For the $\mathrm{pH}$ value of less than 3 or higher than 11, the destabilization potential is considerably diminished, the produced micro-flocs will not be apt to combine into large flocs leading to small coagulation performance [1]. 
Table 3. Parameters influencing coagulation/flocculation [1] [9] [36].

\begin{tabular}{ccc}
\hline Coagulant implementations & Raw water features & Coagulation circumstances \\
\hline Coagulant type (metallic salts & $\mathrm{pH}$, alkalinity, turbidity, ionic & Rapid mixing: Speed \& time \\
and polymers) & force, DOM, organic matter & Slow mixing: Speed \& time \\
Coagulant dosage & composition, temperature & Settling period \\
Coagulant aid & & \\
\hline
\end{tabular}

As a rule, the injection of coagulant implemented is a function of the content of suspended solids or content of water. Nevertheless, extreme treatment performance occurs at an optimum injection and diminishes once the coagulant is overdosed [1] [36]. The reversely charged colloidal particles provoked by the coagulant overdose leads to colloids re-stabilization, thus, reducing the coagulation effectiveness [1] [36].

To satisfy the requirements of Disinfectants and Disinfection By-products Rule (DBPR), EC was proposed by the United States Environment Protection Agency (USEPA) [1] [36] for reducing DBP formation via bigger reduction of NOM through modifying coagulant sort, dosage, and $\mathrm{pH}$. Usually, the used alum injection spreads from 5 - $150 \mathrm{mg} / \mathrm{L}$ for EC [1] [36]. Because of the health worry concerning aluminum, ferric chloride is utilized as an alternative coagulant, particularly for water bodies with small turbidity, elevated dissolved matter and a moderate $\mathrm{pH}[1]$ [36].

\subsubsection{Theory of Coagulation}

Coagulants are utilized to destabilize the negatively charged colloids and dissolved matters in aqueous solution. Following the classical theory, four mechanisms of coagulation involve the double layer compression, charge neutralization, adsorption and inter-particle bridging, and enmeshment in a precipitate (Figure 3) [1] [36].

The negatively charged colloidal particles attract ions of opposite charge to generate a dense layer adjacent to the particle that is known as the Stern layer [36]. The diffuse layer is produced as the consequence of dynamic equilibrium among excess positive ions attracted by the negatively charged core colloids and repulsion force from the Stern layer. Such two layers in the interfacial region of colloid particles are famous as the double-layer [1] [36]. Once a coagulant (positively charged) is introduced into a colloidal system, the double-layer will be compressed due to electrostatic attraction among the ions and colloids. Even though double layer compression does not control the colloid destabilization process in water treatment, it is a critical destabilization mechanism in natural aquatic systems, such as the formation of delta in estuaries [1] [36].

In the charge neutralization route, the destabilization of colloids occurs via neutralization through electrostatic interaction of the coagulant with counter-ions. Inter-particle bridging destabilization happens if polyelectrolytes with highly active surface and linear or branched structures are utilized as coagulation aid to promote the aggregation of micro-flocs throughout the flocculation 
(a)

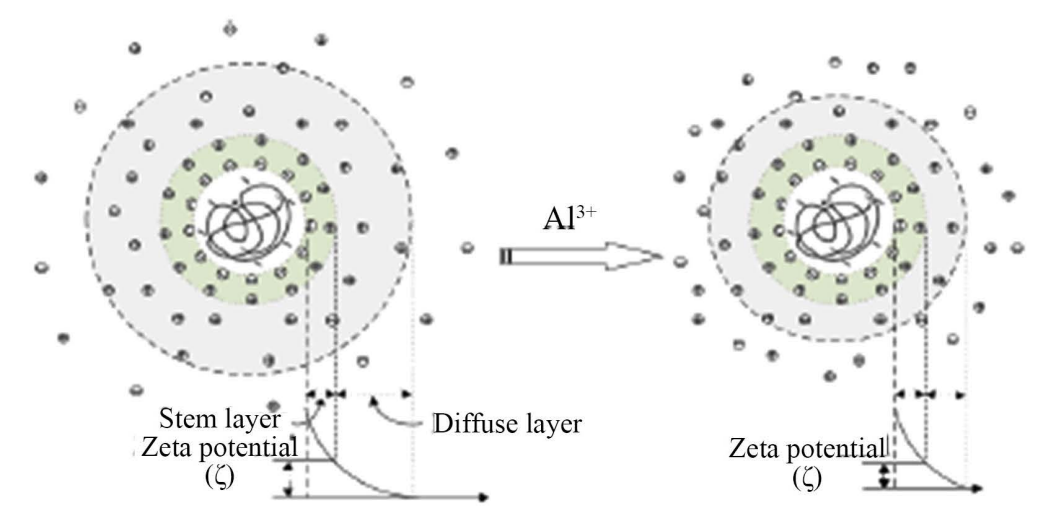

(b)

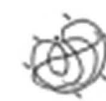

$\mathrm{AOM}$

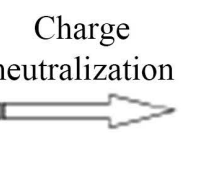

Al hydroxopolymer

(c)

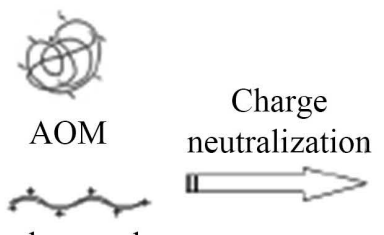

Al hydroxopolymer

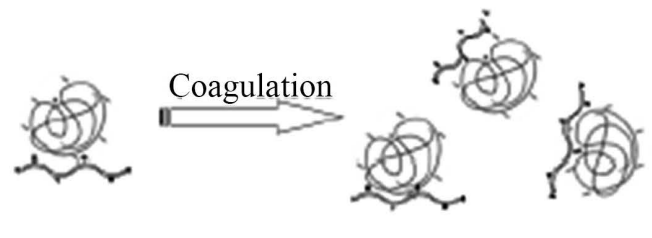

(d)
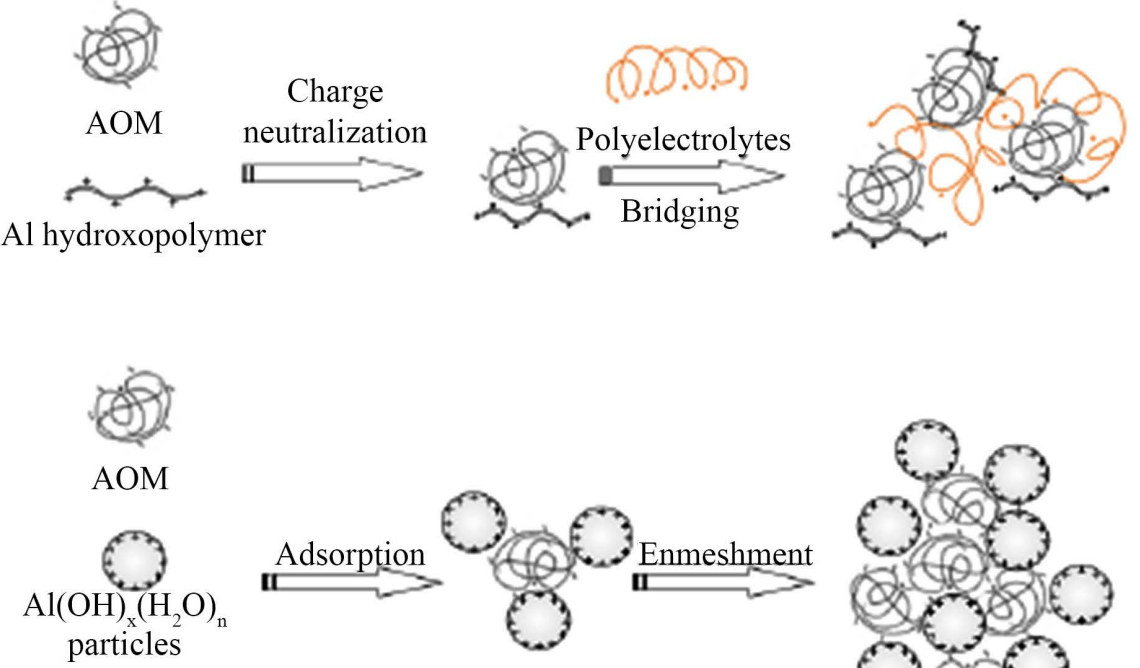

Figure 3. Pathways of coagulation process: (a) Double layer compression; (b) Charge neutralization; (c) Inter-particle bridging; (d) Sweep coagulation [1].

process. The polymer adsorbs on colloidal particle and then extends the linear or branched-chain to attach other particles, consequently, forming an inter-particle bridge. The generation of hydroxide precipitate takes place at higher coagulation dosages. The insoluble, amorphous precipitates entrap or enmesh colloids and the method is known as sweep coagulation or enmeshment [1] [36].

\subsection{Eliminating AOM via Coagulation}

As mentioned above, aluminum salts, particularly alum, remain the most broadly 
utilized coagulants to reduce turbidity and color formed by NOM in surface waters and many groundwaters [1] [9]. With their negatively charged surface, algal cells are well eliminated (>95\%) throughout coagulation and flocculation methods in potable water treatment [9]. The AOM, including both EOM and IOM, originated from an algal cell, constitutes a significant part of NOM in the algae-laden water body. AOM is not well eliminated well via coagulation [9] and provokes severe effects on water treatment efficiency, comprising higher coagulant demand, fouling of the membrane, clogging of the adsorption sites of activated carbon, and formation of DBPs [1] [9] [36].

For AOM-laden water, the efficiency of aluminum and ferric coagulants was discovered to be similar, even if the optimum $\mathrm{pH}$ domain of coagulation by aluminum was higher than that of ferric coagulants [1] [9]. Eliminating effectiveness for both algal cells and AOM is mostly following the $\mathrm{pH}$ and coagulant dosage, due to the occurrence of excessive negative charge on AOM [9] [26]. The electrostatic interactions on coagulation are estimated by the ratio of positive and negative charge in aqueous solution. A strong stoichiometric relationship, among algal cell surface area and alum dosage, was found and a higher alum dosage was needed as a consequence of the coexistence of EOM and algal cells [1]. Eliminating DOM in algae-laden surface water was studied employing $\mathrm{PACl}$ as the coagulant. The aromatic-like substances with a small fraction in NOM were reduced with algae due to coagulation based on the analysis of DOC, SUVA, and fluorescence excitation-emission (EEM) matrix spectroscopy, while the fulvic-like and tryptophon-like substances were not reduced [1] [9].

Researchers [1] mentioned a reduction of $38.7 \%$ and $51.4 \%$ in terms of DOC and $\mathrm{UV}_{254}$, respectively from the IOM of $M$. aeruginosa obtained by EC at an alum dose of $5 \mathrm{mg} / \mathrm{L}$ as $\mathrm{Al}$. The maximum reduction of $42.3 \%$ and $61.5 \%$ was achieved at $\mathrm{pH} 6.5$ for DOC and $\mathrm{UV}_{254}$, respectively. A comparison with DOC, the higher $\mathrm{UV}_{254}$ removal indicated the superiority of alum to remove the aromatic substances present in IOM of $M$. aeruginosa. Another research was carried out to investigate the coagulation performance to remove IOM derived from $M$. aeruginosa spiked in raw water [1]. The results indicated that the removal efficiency was dependent on $\mathrm{pH}$, type of coagulant and its dosage. The IOM removal efficiency was $46 \%$ for ferric sulfate and $41 \%$ for aluminum sulfate. The polysaccharides and proteins in IOM were mainly removed with higher efficiency than other components [1].

Gonzalez-Torres et al. [110] studied the physical floc features via following the structure of algal and cyanobacterial flocs formed by five species (green algae $(C$. vulgaris) and cyanobacteria ( $M$. aeruginosa (strain CS-564), $M$. aeruginosa (strain CS-555/01), Dolichospermum circinale and Cylindrospermopsis raciborskii) employing alum at varying injections and $\mathrm{pH}$ estimates. $D$. circinale, $C$. raciborskii, and $M$. aeruginosa (CS-564) formed big flocs (2 - $9 \mathrm{~mm}$ ), while $M$. aeruginosa (CS-555) and $C$. vulgaris formed smaller flocs $(<2 \mathrm{~mm})$. Whereas dissimilarities in physical floc characteristics were detected to end in alterations in coagulation pathway, the cell morphology and the AOM composition were 

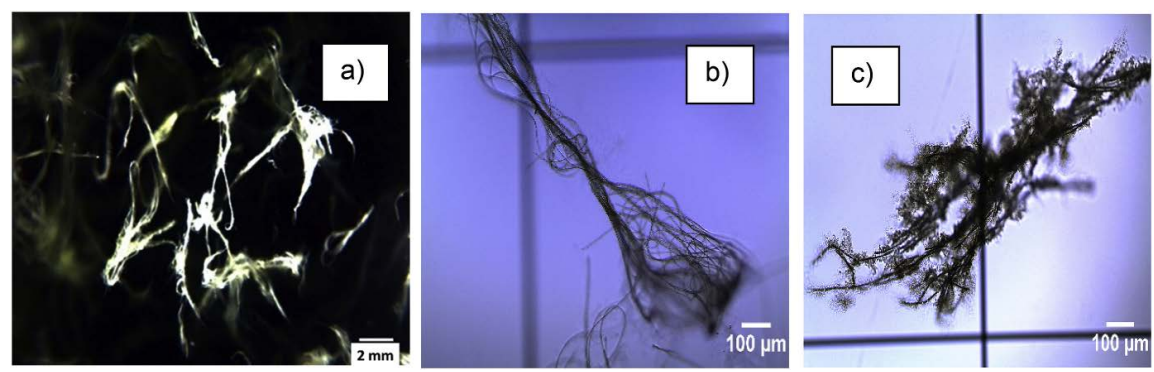

Figure 4. Light microscope image of the flocs formed by (a) M. aeruginosa CS-564, (b) $C$. raciborskii, and (c) D. circinale [110].

the most influential variables. Following floc features may provide a quick insight at the plant for trouble shooting, particularly through the use of the in situ techniques and furnish a pathway by which floc characteristics can be tailored to downstream processes (Figure 4).

\section{Conclusion}

The unwanted presence of AOM in source waters greatly influences the treatability and safety of potable water. To diminish the hazard of the breakout of waterborne diseases and extenuate the likely toxic DBP generation, multiple barriers, comprising coagulation, adsorption, and filtration methods are utilized before to disinfection in potable WTPs. The NOM, comprising fulvic and humic acids as major precursors of DBPs, has drawn large notice. Nevertheless, the AOM comprised of both EOM and IOM as the DBPs precursors had been studied broadly inside the whole potable water treatment techniques. As the primary treatment process, AOM removal by coagulation-flocculation has been noted in many studies, even if most of the research concentrated on reduction effectiveness for one or two algal species. Zhao et al. [1] evaluated the chemical properties like AOM composition, MW distribution throughout numerous growth phases. They found that such features are linked to the coagulation efficiency. In fact, such characteristics are a function of species and growth phase. Thorough investigations following coagulation effectiveness of different AOM to the key features like the hydrophobicity, hydrophilicity, and SUVA are needed [111].

\section{Acknowledgements}

This research has been funded by the Research Deanship of University of Ha'il, Saudi Arabia, through the Project RG-191190.

\section{Conflicts of Interest}

The authors declare no conflicts of interest regarding the publication of this paper.

\section{References}

[1] Zhao, Z. (2020) Effects of Drinking Water Treatment Processes on Removal of Al- 
gal Matter and Subsequent Water Quality. PhD Thesis, The University of Western Ontario, Ontario. https://ir.lib.uwo.ca/etd/6827

[2] Magwaza, S.T., Magwaza, L.S., Odindo, A.O. and Mditshwa, A. (2020) Hydroponic Technology as Decentralised System for Domestic Wastewater Treatment and Vegetable Production in Urban Agriculture: A Review. Science of the Total Environment, 698, Article ID: 134154. https://doi.org/10.1016/j.scitotenv.2019.134154

[3] Jin, X., Xu, Q. and Huang, C. (2005) Current Status and Future Tendency of Lake Eutrophication in China. Science China Life Sciences, 48, 948-954.

[4] Xu, Y., Cai, Q., Ye, L., Zhou, S. and Han, X. (2009) Spring Diatom Blooming Phases in a Representative Eutrophic Bay of the Three-Gorges Reservoir, China. Journal of Freshwater Ecology, 24, 191-198. https://doi.org/10.1080/02705060.2009.9664283

[5] Liu, X., Lu, X. and Chen, Y. (2011) The Effects of Temperature and Nutrient Ratios on Microcystis Blooms in Lake Taihu, China: An 11-Year Investigation. Harmful Algae, 10, 337-343. https://doi.org/10.1016/j.hal.2010.12.002

[6] Anderson, D.M., Glibert, P.M. and Burkholder, J.M. (2002) Harmful Algal Blooms and Eutrophication: Nutrient Sources, Composition, and Consequences. Estuaries, 25, 704-726. https://doi.org/10.1007/BF02804901

[7] Ramsdell, J., Anderson, D. and Glibert, P. (2005) Harrness: Harmful Algal Research and Response: A National Environmental Science Strategy 2005-2015. Ecological Society of America, Washington DC.

[8] Knappe, D.R.U., Belk, R.C., Birley, D.S., Gandy, S.R., Rastogi, N. and Rike, A.H. (2004) Algae Detection and Removal Strategies for Drinking Water Treatment Plants.

[9] Ghernaout, B., Ghernaout, D. and Saiba, A. (2010) cyanotoxins Removal by Coagulation/Flocculation: A Review. Desalination and Water Treatment, 20, 133-143. https://doi.org/10.5004/dwt.2010.1202

[10] Ministry of Environmental Protection of the People's Republic of China (2011) China Environment Bulletin.

[11] Yang, J., Yu, X.Q., Liu, L.M., Zhang, W.J. and Guo, P.Y. (2012) Algae Community and Trophic State of Subtropical Reservoirs in Southeast Fujian, China. Environmental Science and Pollution Research, 19, 1432-1442. https://doi.org/10.1007/s11356-011-0683-1

[12] Becker, R.H., Sultan, M.I., Boyer, G.L., Twiss, M.R. and Konopko, E. (2009) Mapping Cyanobacterial Blooms in the Great Lakes Using MODIS. Journal of Great Lakes Research, 35, 447-453. https://doi.org/10.1016/j.jglr.2009.05.007

[13] Wu, P., Qin, B., Yu, G., Deng, J. and Zhou, J. (2016) Effects of Nutrient on Algae Biomass during Summer and Winter in Inflow Rivers of Taihu Basin, China. Water Environment Research, 88, 665-672. https://doi.org/10.2175/106143016X14609975746767

[14] Bridgeman, T.B., Chaffin, J.D. and Filbrun, J.E. (2013) A Novel Method for Tracking Western Lake Erie Microcystis Blooms, 2002-2011. Journal of Great Lakes Research, 39, 83-89. https://doi.org/10.1016/j.jglr.2012.11.004

[15] Michalak, A.M., Anderson, E.J., Beletsky, D., Boland, S., Bosch, N.S., Bridgeman, T.B., Chaffin, J.D., Cho, K., Confesor, R., Daloglu, I., Depinto, J.V., Evans, M.A., Fahnenstiel, G.L., He, L., Ho, J.C., Jenkins, L., Johengen, T.H., Kuo, K.C., Laporte, E., Liu, X., McWilliams, M.R., Moore, M.R., Posselt, D.J., Richards, R.P., Scavia, D., Steiner, A.L., Verhamme, E., Wright, D.M. and Zagorski, M.A. (2013) Record-Setting Algal Bloom in Lake Erie Caused by Agricultural and Meteorological Trends Consistent with 
Expected Future Conditions. Proceedings of the National Academy of Sciences of the United States of America, 110, 6448-6452. https://doi.org/10.1073/pnas.1216006110

[16] Pick, F.R. (2016) Blooming Algae: A Canadian Perspective on the Rise of Toxic Cyanobacteria. Canadian Journal of Fisheries and Aquatic Science, 73, 1-10. https://doi.org/10.1139/cjfas-2015-0470

[17] U.S. EPA (2015) Algal Toxin Risk Assessment and Management Strategic Plan for Drinking Water. Office of Water, Cincinnati.

[18] Liu, C. and Zheng, H. (2002) South-to-North Water Transfer Schemes for China. International Journal of Water Resources Development, 18, 453-471. https://doi.org/10.1080/0790062022000006934

[19] Wang, Z., Shao, D., Yang, H. and Yang, S. (2015) Prediction of Water Quality in South to North Water Transfer Project of China Based on GA-Optimized General Regression Neural Network. Water Science \& Technology Water Supply, 15, 150-157. https://doi.org/10.2166/ws.2014.099

[20] Hu, Y.R., Zhang, T.Y., Jiang, L., Luo, Y., Yao, S.J., Zhang, D., Lin, K.F. and Cui, C.Z. (2019) Occurrence and Reduction of Antibiotic Resistance Genes in Conventional and Advanced Drinking Water Treatment Processes. Science of the Total Environment, 669, 777-784. https://doi.org/10.1016/j.scitotenv.2019.03.143

[21] Marais, S.S., Ncube, E.J., Msagati, T.A.M., Mamba, B.B. and Nkambule, T.T.I. (2018) Comparison of Natural Organic Matter Removal by Ultrafiltration, Granular Activated Carbon Filtration and Full Scale Conventional Water Treatment. Journal of Environmental Chemical Engineering, 6, 6282-6289.

https://doi.org/10.1016/j.jece.2018.10.002

[22] Zhang, S.Y., Gitungo, S., Axe, L., Dyksen, J.E. and Raczko, R.F. (2016) A Pilot Plant Study Using Conventional and Advanced Water Treatment Processes: Evaluating Removal Efficiency of Indicator Compounds Representative of Pharmaceuticals and Personal Care Products. Water Research, 105, 85-96. https://doi.org/10.1016/j.watres.2016.08.033

[23] Ghernaout, D. and Ghernaout, B. (2012) On the Concept of the Future Drinking Water Treatment Plant: Algae Harvesting from the Algal Biomass for Biodiesel Production: A Review. Desalination and Water Treatment, 49, 1-18. https://doi.org/10.1080/19443994.2012.708191

[24] Fang, J.Y., Yang, X., Ma, J., Shang, C. and Zhao, Q.A. (2010) Characterization of Algal Organic Matter and Formation of DBPs from Chlor(am)ination. Water Research, 44, 5897-5906. https://doi.org/10.1016/j.watres.2010.07.009

[25] Ghernaout, D., Moulay, S., Ait Messaoudene, N., Aichouni, M., Naceur, M.W. and Boucherit, A. (2014) Coagulation and Chlorination of NOM and Algae in Water Treatment: A Review. International Journal of Environmental Monitoring and Analysis, 2, 23-34. https://doi.org/10.11648/j.ijema.s.2014020601.14

[26] Coral, L.A., Zamyadi, A., Barbeau, B., Bassetti, F.J., Lapolli, F.R. and Prévost, M. (2013) Oxidation of Microcystis aeruginosa and Anabaena flos-aquae by Ozone: Impacts on Cell Integrity and Chlorination by-Product Formation. Water Research, 47, 2983-2994. https://doi.org/10.1016/j.watres.2013.03.012

[27] Tomlinson, A., Drikas, M. and Brookes, J.D. (2016) The Role of Phytoplankton as Pre-Cursors for Disinfection by-Product Formation upon Chlorination. Water Research, 102, 229-240. https://doi.org/10.1016/j.watres.2016.06.024

[28] Hua, L.C., Lin, J.L., Chen, P.C. and Huang, C.P. (2017) Chemical Structures of Extra- and Intra-Cellular Algogenic Organic Matters as Precursors to the Formation of 
Carbonaceous Disinfection Byproducts. Chemical Engineering Journal, 328, 1022-1030. https://doi.org/10.1016/j.cej.2017.07.123

[29] Hua, L.-C., Lin, J.-L., Syue, M.-Y., Huang, C. and Chen, P.-C. (2018) Optical Properties of Algogenic Organic Matter within the Growth Period of Chlorella sp. and Predicting Their Disinfection by-Product Formation. Science of the Total Environment, 621, 1467-1474. https://doi.org/10.1016/j.scitotenv.2017.10.082

[30] Ghernaout, D., Benblidia, C. and Khemici, F. (2015) Microalgae Removal from Ghrib Dam (Ain Defla, Algeria) Water by Electroflotation Using Stainless Steel Electrodes. Desalination and Water Treatment, 54, 3328-3337. https://doi.org/10.1080/19443994.2014.907749

[31] Ghernaout, D., Badis, A., Braikia, G., Matâam, N., Fekhar, M., Ghernaout, B. and Boucherit, A. (2017) Enhanced Coagulation for Algae Removal in a Typical Algeria Water Treatment Plant. Environmental Engineering and Management Journal, 16, 2303-2315. https://doi.org/10.30638/eemj.2017.238

[32] Al Arni, S., Amous, J. and Ghernaout, D. (2019) On the Perspective of Applying of a New Method for Wastewater Treatment Technology: Modification of the Third Traditional Stage with Two Units, One by Cultivating Microalgae and Another by Solar Vaporization. International Journal of Environmental Sciences \& Natural Resources, 16, Article ID: 555934. https://doi.org/10.19080/IJESNR.2019.16.555934

[33] Kellali, Y. and Ghernaout, D. (2019) Physicochemical and Algal Study of Three Dams (Algeria) and Removal of Microalgae by Enhanced Coagulation. Applied Engineering, 3, 56-64.

[34] Ghernaout, D. (2019) Electrocoagulation Process for Microalgal Biotechnology: A Review. Applied Engineering, 3, 85-94.

[35] Ghernaout, D., Ghernaout, B. and Naceur, M.W. (2011) Embodying the Chemical Water Treatment in the Green Chemistry: A Review. Desalination, 271, 1-10. https://doi.org/10.1016/j.desal.2011.01.032

[36] Ghernaout, D., Ghernaout, B. and Kellil, A. (2009) Natural Organic Matter Removal and Enhanced Coagulation as a Link between Coagulation and Electrocoagulation. Desalination and Water Treatment, 2, 203-222.

https://doi.org/10.5004/dwt.2009.116

[37] Ghernaout, D. (2014) The Hydrophilic/Hydrophobic Ratio vs. Dissolved Organics Removal by Coagulation: A Review. Journal of King Saud University-Science, 26, 169-180. https://doi.org/10.1016/j.jksus.2013.09.005

[38] Ghernaout, D., Al-Ghonamy, A.I., Boucherit, A., Ghernaout, B., Naceur, M.W., Ait Messaoudene, N., Aichouni, M., Mahjoubi, A.A. and Elboughdiri, N.A. (2015) Brownian Motion and Coagulation Process. American Journal of Environmental Protection, 4, 1-15. https://doi.org/10.11648/j.ajeps.s.2015040501.11

[39] Ghernaout, D., Al-Ghonamy, A.I., Naceur, M.W., Boucherit, A., Messaoudene, N.A., Aichouni, M., Mahjoubi, A.A. and Elboughdiri, N.A. (2015) Controlling Coagulation Process: From Zeta Potential to Streaming Potential. American Journal of Environmental Protection, 4, 16-27. https://doi.org/10.11648/j.ajeps.s.2015040501.12

[40] Ghernaout, D. and Boucherit, A. (2015) Review of Coagulation's Rapid Mixing for NOM Removal. Journal of Research \& Developments in Chemistry, 2015, Article ID: 926518. https://doi.org/10.5171/2015.926518

[41] Ghernaout, D. (2017) Entropy in the Brownian Motion (BM) and Coagulation Background. Colloid and Surface Science, 2, 143-161. 
[42] Ghernaout, D., Simoussa, A., Alghamdi, A., Ghernaout, B., Elboughdiri, N., Mahjoubi, A., Aichouni, M. and El-Wakil, A.E.A. (2018) Combining Lime Softening with Alum Coagulation for Hard Ghrib Dam Water Conventional Treatment. International Journal of Advances in Applied Sciences, 5, 61-70. https://doi.org/10.21833/ijaas.2018.05.008

[43] Djezzar, S., Ghernaout, D., Cherifi, H., Alghamdi, A., Ghernaout, B. and Aichouni, M. (2018) Conventional, Enhanced, and Alkaline Coagulation for Hard Ghrib Dam (Algeria) Water. World Journal of Applied Chemistry, 3, 41-55. https://doi.org/10.11648/j.wjac.20180302.12

[44] Ghernaout, D., Ghernaout, B. and Boucherit, A. (2008) Effect of pH on Electrocoagulation of Bentonite Suspensions in Batch Using Iron Electrodes. Journal of Dispersion Science and Technology, 29, 1272-1275. https://doi.org/10.1080/01932690701857483

[45] Ghernaout, D., Ghernaout, B., Boucherit, A., Naceur, M.W., Khelifa, A. and Kellil, A. (2009) Study on Mechanism of Electrocoagulation with Iron Electrodes in Idealised Conditions and Electrocoagulation of Humic Acids Solution in Batch Using Aluminium Electrodes. Desalination and Water Treatment, 8, 91-99. https://doi.org/10.5004/dwt.2009.668

[46] Ghernaout, D., Mariche, A., Ghernaout, B. and Kellil, A. (2010) Electromagnetic Treatment-Bi-Electrocoagulation of Humic Acid in Continuous Mode Using Response Surface Method for Its Optimization and Application on Two Surface Waters. Desalination and Water Treatment, 22, 311-329. https://doi.org/10.5004/dwt.2010.1120

[47] Ghernaout, D., Irki, S. and Boucherit, A. (2014) Removal of $\mathrm{Cu}^{2+}$ and $\mathrm{Cd}^{2+}$, and Humic Acid and Phenol by Electrocoagulation Using Iron Electrodes. Desalination and Water Treatment, 52, 3256-3270. https://doi.org/10.1080/19443994.2013.852484

[48] Ghernaout, D., Ghernaout, B., Saiba, A., Boucherit, A. and Kellil, A. (2009) Removal of Humic Acids by Continuous Electromagnetic Treatment Followed by Electrocoagulation in Batch Using Aluminium Electrodes. Desalination, 239, 295-308. https://doi.org/10.1016/j.desal.2008.04.001

[49] Ghernaout, D., Naceur, M.W. and Ghernaout, B. (2011) A Review of Electrocoagulation as a Promising Coagulation Process for Improved Organic and Inorganic Matters Removal by Electrophoresis and Electroflotation. Desalination and Water Treatment, 28, 287-320. https://doi.org/10.5004/dwt.2011.1493

[50] Ghernaout, D. and Elboughdiri, N. (2020) Removing Antibiotic-Resistant Bacteria (ARB)Carrying Genes (ARGs): Challenges and Futuretrends. Open Access Library Journal, 7, e6003. https://doi.org/10.4236/oalib.1106003

[51] Ghernaout, D. (2017) Microorganisms' Electrochemical Disinfection Phenomena. EC Microbiology, 9, 160-169.

[52] Ghernaout, D., Alghamdi, A. and Ghernaout, B. (2019) Microorganisms' Killing: Chemical Disinfection vs. Electrodisinfection. Applied Engineering, 3, 13-19.

[53] Ghernaout, D. (2019) Greening Electrocoagulation Process for Disinfecting Water. Applied Engineering, 3, 27-31.

[54] Ghernaout, D. (2019) Electrocoagulation and Electrooxidation for Disinfecting Water: New Breakthroughs and Implied Mechanisms. Applied Engineering, 3, 125-133.

[55] Ghernaout, D. (2019) Virus Removal by Electrocoagulation and Electrooxidation: New Findings and Future Trends. Journal of Environmental Science and Allied Re- 
search, 2019, 85-90. https://doi.org/10.29199/2637-7063/ESAR-202024

[56] Ghernaout, D. and Elboughdiri, N. (2019) Electrocoagulation Process Intensification for Disinfecting Water: A Review. Applied Engineering, 3, 140-147.

[57] Ghernaout, D. and Elboughdiri, N. (2019) Iron Electrocoagulation Process for Disinfecting Water: A Review. Applied Engineering, 3, 154-158.

[58] Ghernaout, D. (2019) Disinfection via Electrocoagulation Process: Implied Mechanisms and Future Tendencies. EC Microbiology, 15, 79-90.

[59] Ghernaout, D., Laribi, C., Alghamdi, A., Ghernaout, B., Ait Messaoudene, N. and Aichouni, M. (2018) Decolorization of BF Cibacete Blue (CB) and Red Solophenyle 3BL (RS) Using Aluminum Sulfate and Ferric Chloride. World Journal of Applied Chemistry, 3, 32-40. https://doi.org/10.11648/j.wjac.20180302.11

[60] Irki, S., Ghernaout, D., Naceur, M.W., Alghamdi, A. and Aichouni, M. (2018) Decolorization of Methyl Orange (MO) by Electrocoagulation (EC) Using Iron Electrodes under a Magnetic Field (MF). II. Effect of Connection Mode. World Journal of Applied Chemistry, 3, 56-64. https://doi.org/10.11648/j.wjac.20180302.13

[61] Irki, S., Ghernaout, D., Naceur, M.W., Alghamdi, A. and Aichouni, M. (2018) Decolorizing Methyl Orange by Fe-Electrocoagulation Process: A Mechanistic Insight. International Journal of Environmental Chemistry, 2, 18-28. https://doi.org/10.11648/j.ijec.20180201.14

[62] Alshammari, Y., Ghernaout, D., Aichouni, M. and Touahmia, M. (2018) Improving Operational Procedures in Riyadh's (Saudi Arabia) Water Treatment Plants Using Quality Tools. Applied Engineering, 2, 60-71.

[63] Ghernaout, D., Touahmia, M. and Aichouni, M. (2019) Disinfecting Water: Electrocoagulation as an Efficient Process. Applied Engineering, 3, 1-12.

[64] Ghernaout, D., Aichouni, M. and Touahmia, M. (2019) Mechanistic Insight into Disinfection by Electrocoagulation: A Review. Desalination and Water Treatment, 141, 68-81. https://doi.org/10.5004/dwt.2019.23457

[65] Ghernaout, D. (2019) Aeration Process for Removing Radon from Drinking Water: A Review. Applied Engineering, 3, 32-45. https://doi.org/10.11648/j.wjac.20180301.11

[66] Ghernaout, D. (2019) Greening Cold Fusion as an Energy Source for Water Treatment Distillation: A Perspective. American Journal of Quantum Chemistry and Molecular Spectroscopy, 3, 1-5.

[67] Ghernaout, D., Naceur, M.W. and Aouabed, A. (2011) On the Dependence of Chlorine by-Products Generated Species Formation of the Electrode Material and Applied Charge during Electrochemical Water Treatment. Desalination, 270, 9-22. https://doi.org/10.1016/j.desal.2011.01.010

[68] Ghernaout, D. and Naceur, M.W. (2011) Ferrate(VI): In Situ Generation and Water Treatment: A Review. Desalination and Water Treatment, 30, 319-332. https://doi.org/10.5004/dwt.2011.2217

[69] Boucherit, A., Moulay, S., Ghernaout, D., Al-Ghonamy, A.I., Ghernaout, B., Naceur, M.W., Ait Messaoudene, N., Aichouni, M., Mahjoubi, A.A. and Elboughdiri, N.A. (2015) New Trends in Disinfection by-Products Formation upon Water Treatment. Journal of Research \& Developments in Chemistry, 2015, Article ID: 628833. https://doi.org/10.5171/2015.628833

[70] Ghernaout, D. (2017) Water Treatment Chlorination: An Updated Mechanistic Insight Review. Chemistry Research Journal, 2, 125-138.

[71] Ghernaout, D. (2018) Magnetic Field Generation in the Water Treatment Perspec- 
tives: An Overview. International Journal of Advances in Applied Sciences, 5, 193-203. https://doi.org/10.21833/ijaas.2018.01.025

[72] Ghernaout, D. (2018) Disinfection and DBPs Removal in Drinking Water Treatment: A Perspective for a Green Technology. International Journal of Advances in Applied Sciences, 5, 108-117. https://doi.org/10.21833/ijaas.2018.02.018

[73] Ghernaout, D., Aichouni, M. and Alghamdi, A. (2018) Applying Big Data (BD) in Water Treatment Industry: A New Era of Advance. International Journal of Advances in Applied Sciences, 5, 89-97. https://doi.org/10.21833/ijaas.2018.03.013

[74] Ghernaout, D., Alghamdi, A., Aichouni, M. and Touahmia, M. (2018) The Lethal Water Tri-Therapy: Chlorine, Alum, and Polyelectrolyte. World Journal of Applied Chemistry, 3, 65-71. https://doi.org/10.11648/j.wjac.20180302.14

[75] Ghernaout, D. and Elboughdiri, N. (2020) Advanced Oxidation Processes for Wastewater Treatment: Facts and Future Trends. Open Access Library Journal, 7, e6139. https://doi.org/10.4236/oalib.1106139

[76] Ghernaout, D. (2013) Advanced Oxidation Phenomena in Electrocoagulation Process: A Myth or a Reality? Desalination and Water Treatment, 51, 7536-7554. https://doi.org/10.1080/19443994.2013.792520

[77] Ghernaout, D. and Ghernaout, B. (2012) Sweep Flocculation as a Second Form of Charge Neutralization: A Review. Desalination and Water Treatment, 44, 15-28. https://doi.org/10.1080/19443994.2012.691699

[78] Ghernaout, D., Badis, A., Ghernaout, B. and Kellil, A. (2008) Application of Electrocoagulation in Escherichia coli Culture and Two Surface Waters. Desalination, 219, 118-125. https://doi.org/10.1016/j.desal.2007.05.010

[79] Saiba, A., Kourdali, S., Ghernaout, B. and Ghernaout, D. (2010) In Desalination, from 1987 to 2009, the Birth of a New Seawater Pretreatment Process: Electrocoagulation: An Overview. Desalination and Water Treatment, 16, 201-217. https://doi.org/10.5004/dwt.2010.1094

[80] Belhout, D., Ghernaout, D., Djezzar-Douakh, S. and Kellil, A. (2010) Electrocoagulation of a Raw Water of Ghrib Dam (Algeria) in Batch Using Iron Electrodes. Desalination and Water Treatment, 16, 1-9. https://doi.org/10.5004/dwt.2010.1081

[81] Ghernaout, D. and Ghernaout, B. (2011) On the Controversial Effect of Sodium Sulphate as Supporting Electrolyte on Electrocoagulation Process: A Review. Desalination and Water Treatment, 27, 243-254. https://doi.org/10.5004/dwt.2011.1983

[82] Ghernaout, D., Al-Ghonamy, A.I., Naceur, M.W., Ait Messaoudene, N. and Aichouni, M. (2014) Influence of Operating Parameters on Electrocoagulation of C.I. Disperse Yellow 3. Journal of Electrochemical Science and Engineering, 4, 271-283. https://doi.org/10.5599/jese.2014.0065

[83] Ghernaout, D., Al-Ghonamy, A.I., Irki, S., Grini, A., Naceur, M.W., Ait Messaoudene, N. and Aichouni, M. (2014) Decolourization of Bromophenol Blue by Electrocoagulation Process. Trends in Chemical Engineering, 15, 29-39.

[84] Ghernaout, D., Al-Ghonamy, A.I., Ait Messaoudene, N., Aichouni, M., Naceur, M.W., Benchelighem, F.Z. and Boucherit, A. (2015) Electrocoagulation of Direct Brown 2 (DB) and BF Cibacete Blue (CB) Using Aluminum Electrodes. Separation Science and Technology, 50, 1413-1420. https://doi.org/10.1080/01496395.2014.982763

[85] Irki, S., Ghernaout, D. and Naceur, M.W. (2017) Decolourization of Methyl Orange (MO) by Electrocoagulation (EC) Using Iron Electrodes under a Magnetic Field (MF). Desalination and Water Treatment, 79, 368-377. 
https://doi.org/10.5004/dwt.2017.20797

[86] Ghernaout, D. (2018) Electrocoagulation Process: Achievements and Green Perspectives. Colloid and Surface Science, 3, 1-5. https://doi.org/10.11648/j.css.20180301.11

[87] Ghernaout, D., Alghamdi, A. and Ghernaout, B. (2019) Electrocoagulation Process: A Mechanistic Review at the Dawn of Its Modeling. Journal of Environmental Science and Allied Research, 2, 51-67. https://doi.org/10.29199/2637-7063/ESAR-201019

[88] Ghernaout, D. and Elboughdiri, N. (2020) Strategies for Reducing Disinfection by-Products Formation during Electrocoagulation. Open Access Library Journal, 7, e6076. https://doi.org/10.4236/oalib.1106076

[89] Ghernaout, D. and Elboughdiri, N. (2020) Electrocoagulation Process in the Context of Disinfection Mechanism. Open Access Library Journal, 7, e6083. https://doi.org/10.4236/oalib.1106083

[90] Ghernaout, D. and Elboughdiri, N. (2020) Disinfection by-Products: Presence and Elimination in Drinking Water. Open Access Library Journal, 7, e6140.

https://doi.org/10.4236/oalib.1106140

[91] Ghernaout, D. and Elboughdiri, N. (2020) Controlling Disinfection by-Products Formation in Rainwater: Technologies and Trends. Open Access Library Journal, 7, e6162. https://doi.org/10.4236/oalib.1106162

[92] Ghernaout, D. and Ghernaout, B. (2010) From Chemical Disinfection to Electrodisinfection: The Obligatory Itinerary? Desalination and Water Treatment, 16, 156-175. https://doi.org/10.5004/dwt.2010.1085

[93] Ghernaout, D. and Elboughdiri, N. (2019) Mechanistic Insight into Disinfection Using Ferrate(VI). Open Access Library Journal, 6, e5946.

https://doi.org/10.4236/oalib.1105946

[94] Ghernaout, D. and Elboughdiri, N. (2019) Water Disinfection: Ferrate(VI) as the Greenest Chemical: A Review. Applied Engineering, 3, 171-180.

[95] Ghernaout, D. and Elboughdiri, N. (2020) Is Not It Time to Stop Using Chlorine for Treating Water? Open Access Library Journal, 7, e6007.

[96] Ghernaout, D. and Elboughdiri, N. (2020) Should We Forbid the Consumption of Antibiotics to Stop the Spread of Resistances in Nature? Open Access Library Journal, 7, e6138.

[97] Ghernaout, D., Elboughdiri, N. and Ghareba, S. (2020) Fenton Technology for Wastewater Treatment: Dares and Trends. Open Access Library Journal, 7, e6045. https://doi.org/10.4236/oalib.1106045

[98] Ghernaout, D. and Elboughdiri, N. (2020) Magnetic Field Application: An Underappreciated Outstanding Technology. Open Access Library Journal, 7, e6000. https://doi.org/10.4236/oalib.1106000

[99] Ghernaout, D. and Elboughdiri, N. (2020) Antibiotics Resistance in Water Mediums: Background, Facts, and Trends. Applied Engineering, 4, 1-6. https://doi.org/10.4236/oalib.1106003

[100] Ghernaout, D. and Elboughdiri, N. (2019) Water Reuse: Emerging Contaminants Elimination-Progress and Trends. Open Access Library Journal, 6, e5981. https://doi.org/10.4236/oalib.1105981

[101] Ghernaout, D. and Elboughdiri, N. (2020) Electrochemical Technology for Wastewater Treatment: Dares and Trends. Open Access Library Journal, 7, e6020. https://doi.org/10.4236/oalib.1106020 
[102] Ghernaout, D. and Elboughdiri, N. (2019) Upgrading Wastewater Treatment Plant to Obtain Drinking Water. Open Access Library Journal, 6, e5959. https://doi.org/10.4236/oalib.1105959

[103] Ghernaout, D., Elboughdiri, N. and Alghamdi, A. (2019) Direct Potable Reuse: The Singapore NE Water Project as a Role Model. Open Access Library Journal, 6, e5980.

[104] Ghernaout, D., Elboughdiri, N. and Al Arni, S. (2019) Water Reuse (WR): Dares, Restrictions, and Trends. Applied Engineering, 3, 159-170.

[105] Ghernaout, D., Elboughdiri, N. and Ghareba, S. (2019) Drinking Water Reuse: One-Step Closer to Overpassing the "Yuck Factor". Open Access Library Journal, 6, e5895. https://doi.org/10.4236/oalib.1105895

[106] Ghernaout, D. (2019) Brine Recycling: Towards Membrane Processes as the Best Available Technology. Applied Engineering, 3, 71-84.

[107] Ghernaout, D. (2017) Water Reuse (WR): The Ultimate and Vital Solution for Water Supply Issues. International Journal of Sustainable Development Research, 3, 36-46. https://doi.org/10.11648/j.ijsdr.20170304.12

[108] Ghernaout, D. (2018) Increasing Trends towards Drinking Water Reclamation from Treated Wastewater. World Journal of Applied Chemistry, 3, 1-9. https://doi.org/10.11648/j.wjac.20180301.11

[109] Ghernaout, D. (2013) The Best Available Technology of Water/Wastewater Treatment and Seawater Desalination: Simulation of the Open Sky Seawater Distillation. Green and Sustainable Chemistry, 3, 68-88. https://doi.org/10.4236/gsc.2013.32012

[110] Gonzalez-Torres, A., Pivokonsky, M. and Henderson, R.K. (2019) The Impact of Cell Morphology and Algal Organic Matter on Algal Floc Properties. Water Research, 163, Article ID: 114887. https://doi.org/10.1016/j.watres.2019.114887

[111] Naceradska, J., Novotna, K., Cermakova, L., Cajthaml, T. and Pivokonsky, M. (2019) Investigating the Coagulation of Non-Proteinaceous Algal Organic Matter: Optimizing Coagulation Performance and Identification of Removal Mechanisms. Journal of Environmental Sciences, 79, 25-34. https://doi.org/10.1016/j.jes.2018.09.024 